
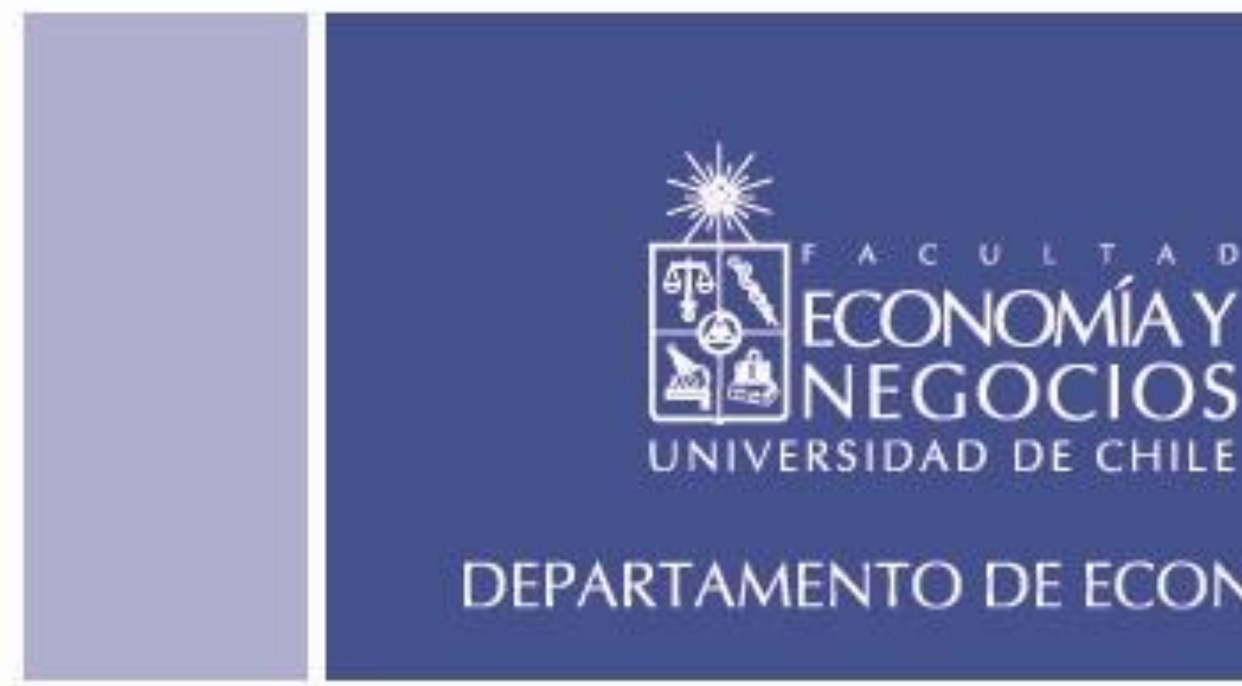

DEPARTAMENTO DE ECONOMÍA

\title{
SOVEREIGN CREDIT RISK IN LATIN AMERICA AND GLOBAL COMMON FACTORS
}

Autores: Manuel R. Agosin y Juan Díaz-Maureira

Santiago, Septiembre de 2012

La serie de Documentos de Trabajo (SDT) del Departamento de Economía de la Universidad de Chile en versión PDF puede descargarse en la dirección electrónica www.econ.uchile.cl/SDT . Para contactar al editor ejecutivo de SDT remitirse a sdt@econ.uchile.cl 


\title{
Sovereign Credit Risk in Latin America and Global Common Factors \\ Manuel R. Agosin and Juan Díaz-Maureira ${ }^{1}$
}

\begin{abstract}
Summary
This paper studies the importance of global common factors in the evolution of sovereign credit risk in a group of emerging economies (15 countries in Latin America for which daily data are available on sovereign credit spreads and CDS quotations from the beginning of 2007 until February 2012). We arrive at three principal results. First, there is robust evidence for the existence of a common factor in the evolution of the two measurements of sovereign credit risk that we use. Second, the comovement between this common factor and our two measures of individual-country sovereign risk rose significantly after the bankruptcy of Lehman Brothers on September 15, 2008, widely regarded as the beginning of the most acute phase of the crisis. We interpret the results as evidence that changes in the availability of foreign capital to emerging economies is dependent less on developments that are internal to these economies than on international liquidity shocks and risk appetite, which in turn depend on global factors exogenous to the recipient economies. Third the long-run values of the measurements of sovereign risk conform to conventional notions of creditworthiness and are closely related to credit ratings. But even here, important credit events also affect long-run sovereign risk measurements.
\end{abstract}

\footnotetext{
${ }^{1}$ Department of Economics, Universidad de Chile. Corresponding author: Agosin (managosin@ fen.uchile.cl).
} 


\section{Sovereign Credit Risk in Latin America and Global Common Factors}

\section{Introduction}

The financial crisis associated with the bursting of the real estate bubble in the United States and some European countries led to the worst financial crisis the world economy has known since the Great Depression and is already widely being referred to as the Great Recession. This crisis, which entered its worst phase after the collapse of Lehman Brothers on September 15, 2008, generated an acute liquidity shortage in the entire global financial system, led to a collapse in stock markets across the world and, in 2009, to a sharp contraction in output in most countries.

Thus, the bankruptcy of Lehman Brothers is seen as the key signal that triggered the potential collapse of the global financial system (saved only by decisive official intervention in most of the large economies of the world). This shock caused the sovereign risk indicators of individual countries to rise sharply, regardless of their individual fundamentals. The impact was particularly acute on emerging economies, which experienced a simultaneous drying up in their access to external financial resources or what Calvo et al (2008) have called a "systemic sudden stop".

Even emerging economies with stable economic and political fundamentals were severely affected by the global financial crisis beginning toward the end of 2008. For example, countries such as Brazil and Chile, whose ample international reserves and/or

fiscal savings reduced to practically zero the probability that they would not honor their debt commitments, also experienced a steep increase in their indicators of sovereign risk. 
This stylized fact suggests that, during a crisis, financial risk indicators of developing economies do not respond to changes in variables that are specific to a particular country and are instead determined by global financial factors that are common to all economies.

The objective of this paper is to measure the impact that such global factors have over the idiosyncratic financial risks of a set of Latin American countries for which complete sovereign risk data are available since the beginning of 2007. Sovereign risk spreads, which had been declining prior to early 2007, indicating growing risk appetite in international financial markets, began an upward trend in the beginning of 2007, perhaps as risk appetite showed signs of reverting. During the first phase, this trend was very gradual, but, as the crisis in the United States and European financial markets began to gather speed, sovereign credit spreads rapidly widened for all Latin American countries. They peaked toward the end of January 2009, and from then on began a gradual return to the levels experienced in early 2007 (see figure 1 for a sample of Latin American countries). Spreads for these countries began to drift upwards again with the intensification of the European sovereign debt crisis.

\section{[insert figure 1]}

We use two measures of sovereign risk. The first one is the emerging markets bond index spreads (EMBI) compiled by J.P. Morgan and reported by Bloomberg on a daily basis. A country's EMBI is determined in basis points (hundredths of one percentage point) and is expressed as the minimum return that a sovereign from a given country must offer for investors to purchase its bonds. It is estimated as the difference between the yield on domestic sovereign bonds in US dollars and the rate on U.S. Treasury 30-year bonds (an investment considered riskless). 
The second indicator we use is the Credit Default Swap (CDS) on a sovereign's debt. The CDS is an instrument to hedge default risk and is akin to the payment of an insurance premium on the default of a given financial instrument, in our case, sovereign bonds of Latin American countries. Our database includes 15 countries in Latin America (there were less countries with data available for CDSs). We use daily data for the period January 2, 2007 through February 23, 2012.

In order to identify the existence of a common factor and to estimate its value, we use two methodologies: principal components and a Kalman filter. Our research yields three principal results. First, there is robust evidence that there exists a common factor in the evolution of sovereign risk premia for the countries considered in the study. This common factor explains roughly 90-95 percent of the variation in our two indicators of sovereign risk. Second, the common factor becomes a much more important explanatory factor after the Lehman bankruptcy. In technical terms, the use of a Kalman filter allows us to show that the common factor itself shifts upward significantly after the Lehman episode. Third, we are able to calculate the long-run, stationary state values of the sovereign credit risk indicators, and these conform to conventional notions of sovereign risk (as reflected in credit ratings).

In spite of the relevance of sovereign credit risk for countries' ability and cost of borrowing on international markets, empirical studies on the subject have been scarce in the international literature. Some studies have focused on estimating the impact of macroeconomic fundamentals on sovereign credit risk in emerging economies (Edwards, 1986; Kamin and Von Kleist, 1999; and Zhang, 2008). Other research efforts share with this paper the attempt to quantify the common factors that explain the comovement of sovereign risk in a group of economies. For example, Délano and Selaive (2005) apply the 
methodology of principal components and use the EMBI as an approximation to sovereign risk in 19 developing economies. They find that, for the period 1998-2004, common factors explain a large share of the variation in the daily EMBI spreads of these countries. Using CDS data, Pan and Singleton (2008) find that the CDSs of Mexico, Turkey and Korea share an important relationship with the VIX index of the United States. Longstaff et al (2011), applying principal components to monthly averages of CDS data for 26 countries over the period October 2000 through January 2010, find that 64 percent of the volatility of CDSs is explained by a common factor.

Our study is close in spirit to the papers by Délano and Selaive (2005) and Longstaff et al (2011). However, it differs from them in three fundamental ways. First, our research utilizes both EMBI and CDS data, while Délano and Selaive (2005) use only EMBI data and Longstaff et al only CDS data. Second, we explore the wealth of information contained in the daily frequency of both series of data, rather than monthly averages, used in Longstaff et al (2011). Third, we use two econometric techniques in order to detect the existence of common factors: principal components and a Kalman filter. The studies cited use only principal components. In addition, we approximate the unobservable common factor by an observed variable (the TED spread) and explore the plausibility that the daily spread data and the coefficient linking the spread to the proxy for the unobservable common factor exhibited breaks after the Lehman credit event.

The paper is organized in the following manner. Section 2 presents the data and derives some stylized facts from their examination. Section 3 contains the principal results, and section 4 concludes.

\section{The data}


As already noted, we use two measures of sovereign financial risk. The first one is the spread on the Emerging Markets Bond Index (EMBI) for each country, calculated by JP Morgan. The exact calculation of a country's EMBI spread considers a package of similar assets from a given sovereign. Therefore, the EMBI spread should be considered a reasonable approximation to the measurement of country risk, but it cannot be observed in the markets themselves. Table 1 summarizes the descriptive statistics for these data.

[Insert Table 1]

The second indicator is the CDS on sovereign debt. As already noted, the CDS is an instrument used to hedge the risk of default on specific debt instruments. A CDS is the yearly premium, expressed in basis points, on insuring against the default of a debt instrument (in our case, a sovereign bond) worth US\$10,000, with a given maturity. We use CDSs on five-year bonds.

In order to understand how a CDS operates, consider the following example. An investor A purchases a government X's bond with a five-year maturity and a face value of US\$ 10,000. In order to insure against X's default, investor A decides to purchase a CDS from hedge fund B for a price, say, of US\$ 100 (one percent of the face value of the bond), which must be paid once a year on a specified date. If government $\mathrm{X}$ defaults at any time before the maturity of the bond, hedge fund B must make restitution of the face value of the bond to investor B, who in turn hands over the bond to hedge fund B. In some cases, where there is a debt restructuring, B pays A the difference between the restructured and the face value of the bond. In the case of any "credit event" (inability or unwillingness of government $\mathrm{X}$ to pay the face value of the bond), investor A stops making yearly premium payments on the CDS. 
The CDS is a more accurate reflection then the EMBI sovereign credit spread of the probability perceived by the market that a government may not honor its debt obligations. The sample available for CDSs is smaller than that for the EMBI. There are only nine Latin American countries for which CDS data are available with a daily frequency. The data we use goes from February 2, 2007 to February 23, 2012. Table 2 shows a summary of the descriptive statistics of CDS data.

[insert table 2]

\section{Identifying the common factor}

In this section, we present the results of estimating the relevance of a common factor underlying the evolution of the risk indicators for all Latin American countries. We use two methodologies to estimate a common unobservable common factor: the methodology of principal components and an estimation using a Kalman filter. For technical details as regards principal components, see Breitung (2005) and (Jäoreskog, 1969); for the Kalman filter methodology, see Geweke (1977), Sargent and Sims (1977), Stock and Watson (1989, 1990), and Watson and Engle (1983). It should be noted that the Kalman filter methodology

works well when the number of endogenous variables is small; as $N$ grows the number of parameters exceed the number that can be estimated. For full technical details, see Hamilton (1994) and Lütkepohl (2005).

Before analyzing the results, it is important to discuss an important technical issue related to the stationarity of the risk indicators. When applying the standard unit root tests found in the time-series literature, one would conclude that the CDS series are I(1); in other words, the series must be differenced once to make them stationary, and estimations should proceed with these latter data. This is what Longstaff et al (2010) do. However, it is difficult to think that, from an economic standpoint, the CDS could be an I(1) series. The 
basic argument to consider the CDS a stationary variable is that it is associated with the probability of default. In fact, this probability can be calculated from the CDS. Since the probability of default must be between zero and one, the CDS series cannot diverge after a shock. Why, then, do unit-root tests conclude that CDS series are I(1)? The explanation probably lies in the fact that we have very short series, and that their available length do not allow us to observe their true dynamics. Therefore, in our estimation we use level indicators of risk.

We are able to estimate the common factor for the EMBI applying the methodology of common factors. We have 20,745 observations (15 countries, with 1,383 daily observations for each country). We estimate an equation by maximum likelihood of the following type:

$$
S P_{i, t}={ }_{i}+{ }_{i} C F_{t}+u_{i, t}
$$

where $S P_{i . t}$ is the EMBI spread for country $i$ on day $t, C F_{t}$ is the common factor we want to estimate, and $u_{i, t}$ is an error term with the usual properties. We estimate the common factor and two parameters for each country: a constant $\left(\alpha_{i}\right)$ and a coefficient $\beta_{i}$. The latter measures the sensitivity of the country's EMBI spread to the common factor. The econometric estimates of the coefficients of the equation and of common factor were obtained using maximum likelihood estimators.

The coefficients $\alpha_{i}$ can be interpreted as the long-run idiosyncratic country risk: when $C F_{t}=0, u_{i, t}=0, S P_{i, t}=\alpha_{i}$ for all $t$. In other words, in the absence of individual country shocks and no changes in international financial markets that affect the spreads of individual countries, the latter should be equal to the $\alpha$ 's. 
Principal component analysis shows that there is only one significant common factor in the EMBI spread dataset. ${ }^{2}$ The estimated common factor is shown in figure 2. As can be seen from casual inspection, the common factor is very similar in its time profile to that of the individual EMBI spread series.

\section{[Insert figure 2]}

With the estimates of the common factor, we can calculate the correlations between the common factor and each country's EMBI spreads. In Table 3 we show the correlation coefficients between the common factor and the individual-country EMBI spreads and the share of the variance not associated with the common factor for the sample as a whole, for 2007, and for the pre- and post-Lehman periods. The average correlation coefficient is extremely high and, for most countries, is above 90 percent. Additionally, the idiosyncratic shock of the model (i.e., the share of the variance in the spread not associated with the common factor) explains a relatively low percentage of the total variance of the EMBI spreads for each of the countries considered, with the exception of Venezuela, Ecuador, Argentina (pre Lehman), and Jamaica (in 2007). Post Lehman, the correlation coefficients for all countries increase considerably, even for the outliers.

\section{[Insert table 3]}

Even though these four countries' sovereign risk premiums are correlated with the common factor, they are less influenced by it and determined to a greater degree by other, unspecified country-specific factors. We interpret these to be variables that make these countries' debt instruments less attractive for international investors than similar instruments in other Latin American countries. At any rate, the results of our econometric exercise tally with conventional wisdom: Venezuela, Ecuador, Argentina and Jamaica have

\footnotetext{
${ }^{2}$ We retain components with eigenvalues greater than one (the Kaiser-Guttman criterion).
} 
pursued policies that are unfriendly to foreign financial investors and have a track record for repudiating their debts.

We also estimated a model of common factors using a Kalman filter, for the full sample and for pre-Lehman and post-Lehman subsamples (see table 4). The exogenous variable is still the EMBI spread, and we estimate the same specification as above but modeling the common factor as a linear function of a dummy variable with value zero before September 15, 2008 and unity afterwards. This binary variable attempts to capture the effect on the common factor of the Lehman bankruptcy. The common factor estimated with this methodology is very similar to the values obtained with the principal components methodology. In fact, the correlation coefficient between both series is 0.98 .

\section{[Insert table 4]}

The estimated coefficient for the dummy variable (Lehman effect) is positive and highly significant. Its value is 0.8 . In other words, the common factor rises by 0.8 after Lehman. The impact on the country EMBIs depends on the $\beta$ 's. For example, the Lehman event added about 65 basis to the Brazilian EMBI and 250 basis points to the Dominican Republic's.

These results are interesting on various counts. As noted, the coefficient of the common factor is highly significant for all countries included in the sample. The range of variation is from 65 for Chile to 808 for Ecuador. Transforming the common factor into basis points by multiplying it by $100,{ }^{3}$ this means that a one basis point increase in the

\footnotetext{
${ }^{3}$ One should also add a constant, so that the common factor never falls below zero. This, of course, does not alter the analysis in this paragraph, since such constant, multiplied by the coefficients attached to the common factor simply shifts by the same amount the constants estimated for each country.
} 
common factor was, on average, during this period, associated with a 0.65 basis point change in Chile's sovereign spread and with an 8.08 point change in Ecuador's. ${ }^{4}$

Although this is more a conjecture than something that we can show with a statistical test, the size of the common factor appears to be correlated to the degree of creditworthiness, level of income per capita, and size of the countries concerned. The most creditworthy countries in the sample according to "objective" data on sovereign spreads or "subjective" credit ratings (Chile, Brazil, Mexico, and Colombia) have the lowest estimated $\beta$ 's, while Ecuador, Argentina, Dominican Republic, and Venezuela have the highest.

The estimated $\alpha$ 's track perceived notions of creditworthiness, corroborating the analytical conclusion that they estimate long-term idiosyncratic country risk factors. Thus, at the lower end, the constant for Chile is estimated at 126 basis points, while it rises to 831 basis points for Venezuela, 771 for Ecuador, and 570 for Argentina. This suggests that, in spite of the comovement of spreads across the region, investors appear to differentiate between different issuers of sovereign debt in ways that conventional wisdom suggests they do.

The results with the two subsamples also lend credence to the hypothesis that the effect of the common factor on country EMBI spreads rose very sharply after Lehman. All $\beta$ 's are significantly higher post Lehman. In addition, the $\alpha$ 's, which one might take to reflect "pure" country risk, also rose significantly. Thus adverse shocks in international capital markets (such as Lehman) appear to have two impacts on sovereign risk spreads: (1) it makes all spreads more sensitive to risk appetite/aversion in international markets; and (2) it tends to push up all spreads independently of the comovement factor.

\footnotetext{
${ }^{4}$ The level of 100 in the normalized common factor is estimated to have been reached just after the Lehman event (at the end of October 2008. Roughly a month later it was at 300.
} 
Rather than trying to estimate the unobservable common factor, an attempt was made to approximate it using an observed variable. We use the TED spread, defined as the difference between LIBOR and the interest rate on Treasury bills (both with a maturity of three months). We estimate OLS equations for each country, in which the sovereign spread (EMBI) is the dependent variable, incorporating the following explanatory variables: the value of the TED spread lagged one day (in order to account for a possible codetermination of the TED spread and the EMBI spreads), the Lehman dummy, and an interactive variable between the lagged TED spread and the Lehman dummy. Again, we estimate the model with the full sample and with the two subsamples (pre- and post-Lehman). The results are shown on table 5 .

\section{[Insert table 5]}

The results show that, for almost all countries in the sample, the TED spread has a positive, high (with point estimates in the range of 0.4 to 0.5 ), and very significant impact on the individual sovereign spread of each country. In the vast majority of countries, the Lehman dummy adds a significant and quantitatively important number of basis points to the constant in the post-Lehman. The interactive variable is also highly significant. The coefficient linking the TED spread to countries' sovereign spreads rises sharply after the Lehman collapse. In most countries, the coefficient exceeds unity after September 15, 2008, which means that, post Lehman, a one point increase in the TED spread - our measure of international financial risk appetite/aversion - leads, on average, to more than a one point increase in country EMBI spreads.

The exceptions are Ecuador (negative coefficient for the TED spread pre Lehman) and Venezuela (negative effect of Lehman on the coefficient linking the TED spread and the EMBI spread). 
The results obtained with the use of the EMBI spreads are pretty robust to a change in the measure of sovereign risk. One may object that the way the EMBI as constructed biases the results in favor of the hypothesis that there is a common factor accounting for the comovement of individual country risk measures. The EMBI spreads are built using the interest rate on 30-year U.S. Treasury bonds. That is, this latter interest rate is subtracted from the interest rate on national bonds to arrive at the EMBI spread. Therefore, by construction, a change in U.S. interest rates will impact all the measured EMBI spreads at the same time. ${ }^{5}$

As an alternative, we apply the same econometric models to country Credit Default Swaps (CDS) as the dependent variable. The estimated common factor using CDSs is almost identical to the one using EMBI spreads. As shown in table 6, there is a high correlation between the common factor, estimated via principal components, and the country CDSs. The only country that does not follow this pattern is Ecuador, where, in fact, the correlation is negative. All correlation coefficients rise significantly after Lehman, and only Ecuador and Venezuela exhibit a high variance in their CDSs not associated with the common factor. For the full sample, the variance of Ecuador's CDS explained by the idiosyncratic shock is 95 percent. For Venezuela's, it is 19 percent.

\section{[Insert table 6]}

Finally, following the same procedure as we did for the EMBI spread, we estimate the common factor through a Kalman filter, with the individual country daily CDS as the

\footnotetext{
${ }^{5}$ It should be noted, however, that the bias involved is in the opposite direction to the findings shown above: a fall in the U.S. Treasury bond rate will cause all EMBIs to rise. In other words, the built-in relationship between the U.S. interest rate (a component of the common factor) and the EMBI spreads is negative. Our findings show a significantly positive relationship between the common factor and the EMBI spreads. This means that, if anything, by using the EMBIs, we could be underestimating the impact of the common factor.
} 
endogenous variable and using as an additional variable the Lehman dummy. The results are shown on table $7 .^{6}$

\section{[Insert table 7]}

The results are very similar to those obtained using the sovereign EMBI spread (shown on table 4). The Lehman shock added a point estimate of 0.9 basis to the common factor explaining all CDSs. The estimated common factor is a highly significant determinant of the country CDSs and its coefficient has an absolute value of between 52 (Chile) and 852 (Argentina). The only anomalous result is for Ecuador, where the common factor has a negative (and significant) coefficient. At the same time, Ecuador exhibits a huge constant (the estimate of the long-run idiosyncratic risk) of 2,304 basis points. Data availability do not allow for an estimation of the parameters of all countries for the preLehman subsample. ${ }^{7}$ However, both $\alpha$ 's and $\beta$ 's are much higher for the post-Lehman period than for the sample as a whole. Again, adverse credit market shocks affect negatively both the level of the CDSs and the extent to which they respond to changes in international financial market conditions.

\section{Conclusions}

Using a sample of Latin American countries since right before the onset of the financial crisis to the end of 2010, this paper has shown that there is a large element of comovement in the variables that are conventionally used to measure sovereign credit risk: the EMBI spread and the CDS on sovereign debt. If the EMBI spread or the CDS on a country's sovereign paper reflected the inherent risk of investing in its bonds, one should

\footnotetext{
${ }^{6}$ Note that CDS data are not available for all countries. Therefore, the countries included in table 7 are Argentina, Brazil, Chile, Colombia, Ecuador, Panama, Peru, Mexico, and Venezuela.

${ }^{7}$ For some days there are no quotes for several countries. The parameters are estimated with a balanced panel, so the absence of data for one or more countries eliminates the possibility of using the data available for other countries.
} 
not expect that changes in these variables would be correlated across countries. To put it in a different way, nothing in the fundamentals of a country such as Chile appeared to justify the enormous swings in its EMBI spread (nor in its sovereign CDS): its EMBI spread went from 78 basis points at the beginning of 2007 to 410 at the end of January 2009 and back to 90 basis points at the end of December 2009. These gyrations have more to do with changes in risk appetite and liquidity conditions on international financial markets than with changes in domestic fundamentals.

We attempted to measure the common factor behind the variations in the EMBI spreads and CDSs and to estimate its impact on sovereign spreads in three different ways three different ways. One was principal component analysis. The second was the use of a Kalman filter and the introduction of a dummy to reflect the effect of the Lehman collapse. In the third set of regressions, we use the TED spread as a proxy for the unobservable common factor and estimate its impact on EMBI spreads before and after Lehman.

We find that the presumption for the existence of a common factor is strong and is substantiated by the data. The estimated common factor and its proxy (the TED spread) are highly significant variables explaining variations in EMBI spreads and CDSs. In addition, we find that the Lehman episode had two distinct effects on country credit risk: a constant effect, by adding basis points to the risk measures, and a trend effect, by raising the value of the common factor. In the regressions using the TED spread as the explanatory variable, the coefficient associated with this proxy for the common factor rises sharply after Lehman. In other words, the impact of Lehman seems to have been to make all Latin American sovereign paper riskier (demanding higher interest rates) and more sensitive to international risk appetite and liquidity conditions. 
This is not to say that country fundamentals play no role in determining the level of risk valuations, be they measured by the EMBI spreads or CDSs. They do. Generally speaking, the constants in our econometric exercises do seem to reflect a ranking according to perceived country risk, with Chile, Brazil, Mexico, and Colombia at the low end of the spectrum and countries such as Ecuador, Venezuela or Argentina at the higher end. However, even these measures of long-run country risk are influenced by international factors: they experience discreet and significant upward movements when international liquidity and risk appetite diminish abruptly.

What does this mean for policy? In the first place, international financial market conditions are fundamental in determining market access and the price a country must pay to borrow internationally, independently of the quality of its policy making or future prospects. This would suggest that a measure of protection against the effects of Lehmanlike episodes, be it through building up reserves or a sovereign wealth fund, is a good idea. Second, countries integrating into international financial markets have to be aware of its dangers. Low interest rates and easy access do not mean that a country has "made it" into the ranks of creditworthy countries. Therefore, treading with care in the brave new world of international financial integration is highly advisable. 


\section{References}

Bai, J. and Ng, S. 2002. Determining the number of factors in approximate factor models. Econometrica, 70 (1):191-221.

Calvo, G., Izquierdo, A., y Mejía, L. F. 2008. Systemic sudden stops: the relevance of balance-sheet effects and financial integration. NBER Working Paper No. 14026. National Bureau of Economic Research, Cambridge, MA. May.

De Jong, P. 1988. The likelihood for a state space model. Biometrika, 75: 165-169.

Delano, V. and Selaive, J. 2005. Spreads soberanos: una aproximación factorial. Documentos de trabajo No. 309, Banco Central de Chile, Santiago.

Duffie, D., Pedersen, L., and Singleton, K. 2003. Modeling sovereign yield spreads: a case study of Russian debt. Journal of Finance, 58(1): 119-59.

Edwards, S. 1986. The pricing of bonds and bank loans in international markets. An empirical analysis of developing countries' foreign borrowing. European Economic Review, 30. (Juan: cita completa, por favor.)

Geweke, J. 1977. The dynamic factor analysis of economic time series models. Latent Variables in Socioeconomic Models. Ed. D. J. Aigner and A. S. Goldberger. Amsterdam: North-Holland.

Hamilton, J. 1994. Time series analysis. Princeton University Press. Princeton, NJ.

Kamin, S., and von Kleist, K. 1999). The evolution and determinants of emerging market credit spreads in the 1990s. Working Paper No. 68. (de dónde?)

Longstaff, F., Pan, J., Pedersen, L. and Singleton, K. 2011. How sovereign is sovereign credit risk? American Economic Journal: Macroeconomics 3: 75-103.

Lütkepohl, H. 2005. New Introduction to Multiple Time Series Analysis. Berlin: Springer-Verlag. 
Pan, J. and Singleton, K. 2008. Default and recovery implicit in the term structure of sovereign CDS spreads. The Journal of Finance, 63 (5). (números de págs.?)

Sargent, T. J., and C. A. Sims. 1977. Business cycle modeling without pretending to have too much a priori economic theory. New Methods in Business Cycle Research: Proceedings from a Conference. Ed. C. A. Sims. Minneapolis: Federal Reserve Bank of Minneapolis.

Stock, J. H., and Watson, M. W. 1989. New indexes of coincident and leading economic indicators. NBER Macroeconomics Annual. Eds. O. J. Blanchard and S. Fischer, vol. 4, 351-394. Cambridge, MA: MIT Press.

Watson, M. W. and Engle, R. F. 1983. Alternative algorithms for the estimation of dynamic factor. MIMIC and varying coefficient regression models. Journal of Econometrics, 23: 385-400.

Zhang, F. X. 2008. Market expectations and default risk Premium in credit default swap prices: a study of Argentine default. Journal of Fixed Income, 18(1): 37-55. 
Figure 1

Daily EMBI spreads for selected countries in Latin America, January 2, 2007 - February 23, 2012

(basis points)

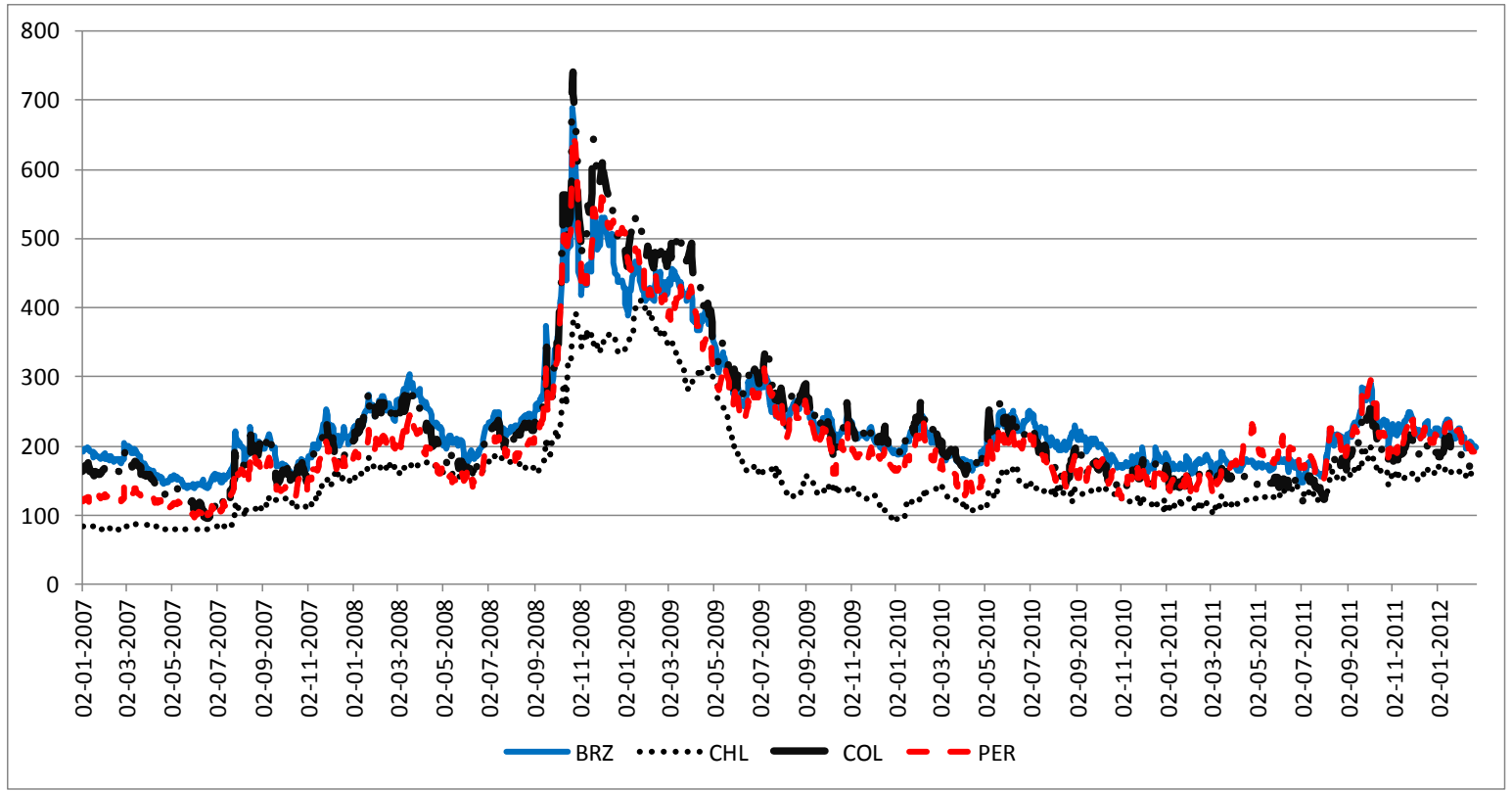




\section{Table 1}

Daily EMBI spreads for 15 Latin American countries, January 2, 2007 - February 23, 2012, descriptive statistics (basis points)

\begin{tabular}{|l|c|c|c|c|}
\hline Country & Mean & Std. Dev. & Min & Max \\
\hline \hline Argentina & 753 & 416 & 185 & 1965 \\
\hline Brazil & 236 & 85 & 138 & 688 \\
\hline Chile & 160 & 73 & 78 & 411 \\
\hline Colombia & 229 & 109 & 95 & 741 \\
\hline Costa Rica & 226 & 129 & 63 & 657 \\
\hline Dominican Republic & 517 & 345 & 122 & 1785 \\
\hline Ecuador & 1177 & 968 & 538 & 5069 \\
\hline El Salvador & 353 & 165 & 99 & 928 \\
\hline Guatemala & 282 & 127 & 114 & 751 \\
\hline Jamaica & 605 & 243 & 222 & 1324 \\
\hline Mexico & 211 & 92 & 89 & 627 \\
\hline Panama & 221 & 106 & 114 & 648 \\
\hline Peru & 213 & 97 & 95 & 653 \\
\hline Uruguay & 286 & 150 & 133 & 907 \\
\hline Venezuela & 960 & 414 & 183 & 1887 \\
\hline Source: Bloomberg's. & & & & \\
\hline
\end{tabular}

Source: Bloomberg's. 
Table 2

Credit Default Swaps on sovereign Latin American debt, February 2, 2007 - February 23, 2012, descriptive statistics

(basis points)

\begin{tabular}{|l|c|c|c|c|}
\hline Country & Mean & Std. Dev. & Min & Max \\
\hline \hline Argentina & 1111 & 1005 & 183 & 4689 \\
\hline Brazil & 150 & 79 & 62 & 586 \\
\hline Chile & 88 & 60 & 12 & 323 \\
\hline Colombia & 169 & 84 & 65 & 600 \\
\hline Mexico & 143 & 91 & 28 & 601 \\
\hline Peru & 156 & 83 & 60 & 586 \\
\hline Venezuela & 1019 & 596 & 151 & 3239 \\
\hline Ecuador & 2039 & 1676 & 534 & 4432 \\
\hline Panama & 158 & 89 & 61 & 587 \\
\hline Source: Bloor & & & &
\end{tabular}

Source: Bloomberg's. 
Figure 2

Unobservable common factor in EMBI spreads of 15 Latin American countries, estimated by principal components (maximum likelihood)

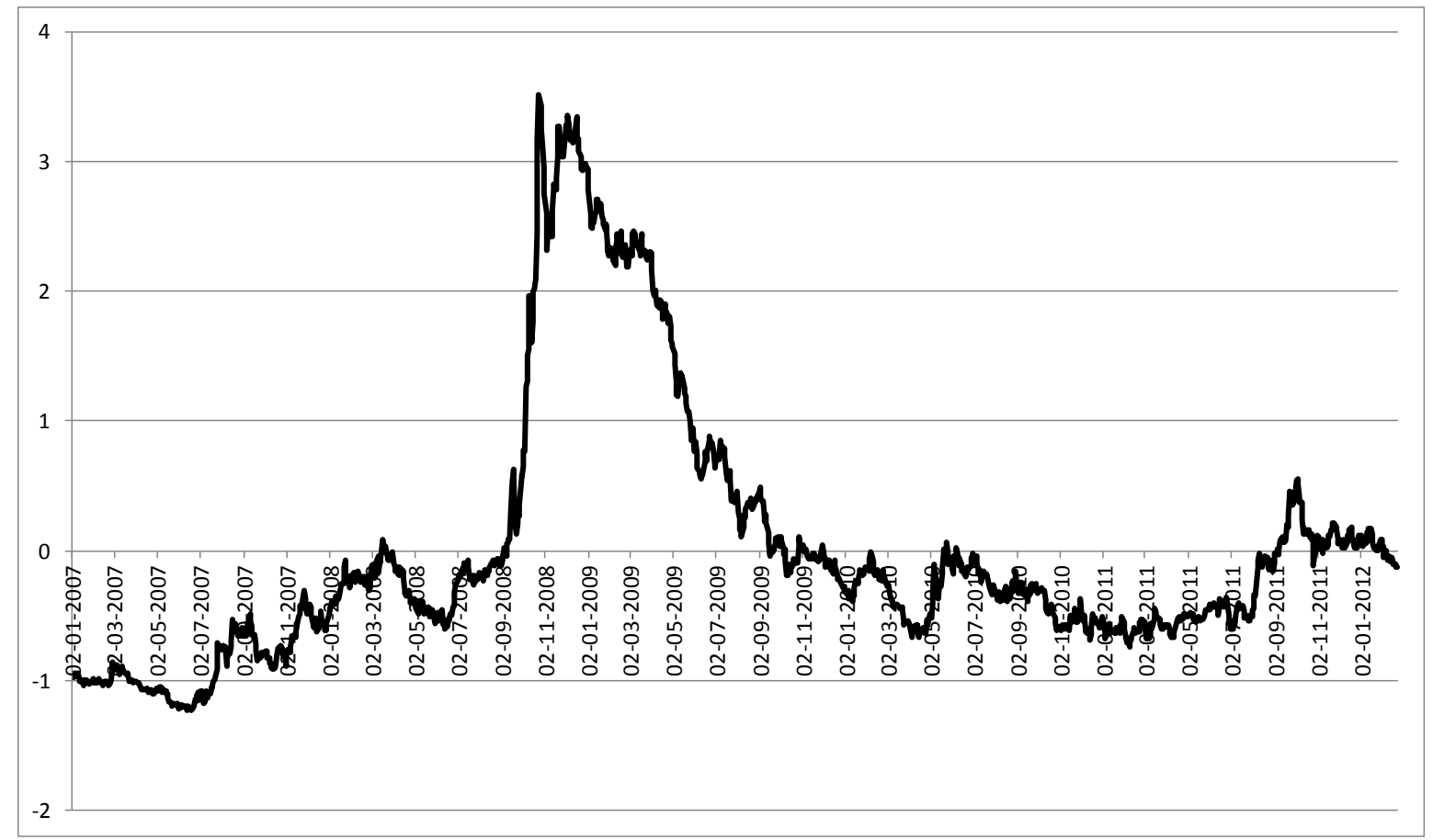

Source: Authors' calculations. 
Table 3

Correlation between the common factor estimated through principal components and individual country EMBI spreads and variance not associated with the common factor, several periods

\begin{tabular}{|l|c|c|c|c|c|c|c|c|}
\hline \multirow{2}{*}{ Country } & \multicolumn{2}{|c|}{ Full sample } & \multicolumn{2}{c|}{ Only 2007 data } & \multicolumn{2}{c|}{ Before 15-09-2008 } & \multicolumn{2}{c|}{ After 15-09-2008 } \\
\cline { 2 - 8 } & Corr. & Var. & Corr. & Var. & Corr. & Var. & Corr. & Var. \\
\hline Argentina & 0.97 & $7 \%$ & 0.75 & $44 \%$ & 0.89 & $21 \%$ & 0.97 & $5 \%$ \\
\hline Brazil & 0.96 & $7 \%$ & 0.88 & $23 \%$ & 0.93 & $14 \%$ & 0.98 & $5 \%$ \\
Chile & 0.96 & $9 \%$ & 0.90 & $19 \%$ & 0.95 & $9 \%$ & 0.97 & $6 \%$ \\
\hline Colombia & 0.96 & $7 \%$ & 0.90 & $19 \%$ & 0.92 & $16 \%$ & 0.98 & $5 \%$ \\
\hline Costa Rica & 0.95 & $9 \%$ & 0.97 & $6 \%$ & 0.97 & $5 \%$ & 0.98 & $4 \%$ \\
\hline Dom. Rep. & 0.98 & $4 \%$ & 0.97 & $6 \%$ & 0.95 & $10 \%$ & 0.97 & $5 \%$ \\
Ecuador & 0.91 & $18 \%$ & -0.16 & $97 \%$ & -0.16 & $98 \%$ & 0.92 & $15 \%$ \\
\hline El Salvador & 0.94 & $11 \%$ & 0.95 & $10 \%$ & 0.95 & $10 \%$ & 0.96 & $7 \%$ \\
\hline Guatemala & 0.97 & $5 \%$ & 0.96 & $9 \%$ & 0.98 & $4 \%$ & 0.97 & $6 \%$ \\
\hline Jamaica & 0.94 & $12 \%$ & 0.85 & $28 \%$ & 0.95 & $10 \%$ & 0.95 & $10 \%$ \\
\hline Mexico & 0.99 & $3 \%$ & 0.95 & $9 \%$ & 0.97 & $5 \%$ & 0.98 & $3 \%$ \\
\hline Panama & 0.98 & $4 \%$ & 0.96 & $8 \%$ & 0.97 & $6 \%$ & 0.99 & $2 \%$ \\
\hline Peru & 0.98 & $4 \%$ & 0.97 & $5 \%$ & 0.96 & $8 \%$ & 0.98 & $4 \%$ \\
\hline Uruguay & 0.96 & $8 \%$ & 0.96 & $9 \%$ & 0.98 & $3 \%$ & 0.98 & $4 \%$ \\
\hline Venezuela & 0.74 & $45 \%$ & 0.88 & $23 \%$ & 0.93 & $13 \%$ & 0.83 & $32 \%$ \\
\hline Source: Authyyyyyyyyyyy
\end{tabular}

Source: Authors' calculations. 
Table 4

Estimation of the model of common factors with a Kalman filter, with the full sample using the Lehman dummy and pre and post Lehman samples; endogenous variable: the EMBI spread; maximum likelihood estimations

\begin{tabular}{|c|c|c|c|c|c|c|c|}
\hline & & \multicolumn{2}{|c|}{ Full Sample } & \multicolumn{2}{|c|}{ Before 15-09-2008 } & \multicolumn{2}{|c|}{ After 15-09-2008 } \\
\hline & & Coef. & Std. Err. & Coef. & Std. Err. & Coef. & Std. Err. \\
\hline & Dummy & 0.8 & 0.1 & - & - & - & - \\
\hline \multirow[t]{2}{*}{ Argentina } & $\beta$ & 364.6 & 8.1 & 124.9 & 5.6 & 392.1 & 9.9 \\
\hline & $\alpha$ & 569.7 & 18.0 & 420.1 & 7.0 & 917.7 & 13.6 \\
\hline \multirow[t]{2}{*}{ Brazil } & $\beta$ & 79.1 & 1.6 & 36.0 & 1.3 & 95.4 & 2.3 \\
\hline & $\alpha$ & 196.5 & 3.8 & 203.5 & 1.8 & 252.4 & 3.2 \\
\hline \multirow[t]{2}{*}{ Chile } & $\beta$ & 65.5 & 1.4 & 36.2 & 1.4 & 77.2 & 2.0 \\
\hline & $\alpha$ & 126.8 & 3.2 & 129.3 & 1.8 & 174.9 & 2.7 \\
\hline \multirow[t]{2}{*}{ Colombia } & $\beta$ & 101.6 & 2.0 & 40.0 & 1.5 & 123.3 & 3.0 \\
\hline & $\alpha$ & 178.0 & 4.9 & 186.1 & 2.0 & 250.4 & 4.2 \\
\hline \multirow[t]{2}{*}{ Costa Rica } & $\beta$ & 117.8 & 2.4 & 63.4 & 2.2 & 143.5 & 3.6 \\
\hline & $\alpha$ & 166.7 & 5.7 & 186.2 & 3.1 & 245.5 & 4.9 \\
\hline \multirow[t]{2}{*}{ Dom. Rep. } & $\beta$ & 313.0 & 6.5 & 112.9 & 4.4 & 356.3 & 8.9 \\
\hline & $\alpha$ & 359.3 & 15.2 & 299.7 & 5.8 & 624.1 & 12.3 \\
\hline \multirow[t]{2}{*}{ Ecuador } & $\beta$ & 808.0 & 19.4 & -9.0 & 3.8 & 984.2 & 28.2 \\
\hline & $\alpha$ & 770.7 & 40.8 & 659.5 & 3.8 & 1433.0 & 36.5 \\
\hline \multirow[t]{2}{*}{ El Salvador } & $\beta$ & 139.1 & 3.3 & 58.1 & 2.2 & 141.5 & 3.8 \\
\hline & $\alpha$ & 283.4 & 7.0 & 206.6 & 2.9 & 425.9 & 5.0 \\
\hline \multirow[t]{2}{*}{ Guatemala } & $\beta$ & 113.9 & 2.4 & 44.1 & 1.5 & 130.2 & 3.4 \\
\hline & $\alpha$ & 225.1 & 5.5 & 207.2 & 2.1 & 319.6 & 4.6 \\
\hline \multirow[t]{2}{*}{ Jamaica } & $\beta$ & 205.2 & 4.8 & 87.8 & 3.4 & 209.7 & 5.6 \\
\hline & $\alpha$ & 501.4 & 10.3 & 391.1 & 4.5 & 710.1 & 7.5 \\
\hline \multirow[t]{2}{*}{ Mexico } & $\beta$ & 84.5 & 1.7 & 34.4 & 1.2 & 94.7 & 2.3 \\
\hline & $\alpha$ & 168.7 & 4.1 & 150.0 & 1.7 & 241.5 & 3.2 \\
\hline \multirow[t]{2}{*}{ Panama } & $\beta$ & 99.3 & 1.9 & 36.1 & 1.3 & 121.3 & 2.9 \\
\hline & $\alpha$ & 170.9 & 4.7 & 178.9 & 1.7 & 241.6 & 4.1 \\
\hline \multirow[t]{2}{*}{ Peru } & $\beta$ & 90.4 & 1.8 & 35.5 & 1.3 & 105.1 & 2.6 \\
\hline & $\alpha$ & 167.8 & 4.3 & 160.0 & 1.7 & 239.5 & 3.6 \\
\hline \multirow[t]{2}{*}{ Uruguay } & $\beta$ & 139.0 & 2.8 & 58.0 & 2.0 & 171.6 & 4.1 \\
\hline & $\alpha$ & 215.6 & 6.7 & 236.3 & 2.8 & 309.9 & 5.8 \\
\hline \multirow[t]{2}{*}{ Venezuela } & $\beta$ & 256.2 & 9.5 & 151.4 & 6.1 & 179.2 & 6.3 \\
\hline & $\alpha$ & 831.2 & 15.5 & 451.8 & 8.0 & 1211.2 & 7.6 \\
\hline \multicolumn{2}{|c|}{ Log Likelihood } & -109850.1 & & -30415.6 & & -71982.6 & \\
\hline \multicolumn{2}{|l|}{ Obs. } & 1343 & & 444 & & 899 & \\
\hline
\end{tabular}

Source: Authors' calculations.

Note: The number of observations refers to observations per country. We use observations for those days in which we have observations for all countries. 
Table 5

OLS estimation of model for EMBI country spreads using TED spreads, the Lehman dummy and an interaction between them as explanatory variables, February 2, 2007 February 23, 2012 (1284 observations)

\begin{tabular}{|c|c|c|c|c|c|c|c|}
\hline & & \multicolumn{2}{|c|}{ Full Sample } & & & \multicolumn{2}{|c|}{ Full Sample } \\
\hline & & Coef. & Std. Err. & & & Coef. & Std. Err. \\
\hline \multirow[t]{5}{*}{ Argentina } & TED & 1.6 & 0.1 & Guatemala & TED & 0.5 & 0.0 \\
\hline & Dummy & 463.9 & 19.8 & & Dummy & 97.8 & 6.3 \\
\hline & Interaction & 1.1 & 0.3 & & Interaction & 0.4 & 0.1 \\
\hline & Cons. & 239.9 & 11.8 & & Cons. & 149.2 & 3.2 \\
\hline & R-squared & 0.60 & & & R-squared & 0.52 & \\
\hline \multirow[t]{5}{*}{ Brazil } & TED & 0.4 & 0.0 & Jamaica & TED & 1.3 & 0.1 \\
\hline & Dummy & 29.4 & 4.3 & & Dummy & 355.1 & 11.6 \\
\hline & Interaction & 0.4 & 0.1 & & Interaction & 0.1 & 0.2 \\
\hline & Cons. & 161.6 & 2.9 & & Cons. & 252.9 & 6.8 \\
\hline & R-squared & 0.62 & & & R-squared & 0.59 & \\
\hline \multirow[t]{5}{*}{ Chile } & TED & 0.5 & 0.0 & Mexico & TED & 0.4 & 0.0 \\
\hline & Dummy & 53.1 & 3.9 & & Dummy & 76.9 & 4.3 \\
\hline & Interaction & 0.1 & 0.1 & & Interaction & 0.4 & 0.1 \\
\hline & Cons. & 76.4 & 2.6 & & Cons. & 108.6 & 2.4 \\
\hline & R-squared & 0.52 & & & R-squared & 0.62 & \\
\hline \multirow[t]{5}{*}{ Colombia } & TED & 0.4 & 0.0 & Panama & TED & 0.4 & 0.0 \\
\hline & Dummy & 33.2 & 5.5 & & Dummy & 32.7 & 5.3 \\
\hline & Interaction & 0.6 & 0.1 & & Interaction & 0.6 & 0.1 \\
\hline & Cons. & 140.8 & 3.4 & & Cons. & 136.8 & 2.8 \\
\hline & R-squared & 0.59 & & & R-squared & 0.57 & \\
\hline \multirow[t]{5}{*}{ Costa Rica } & TED & 0.8 & 0.0 & Peru & TED & 0.4 & 0.0 \\
\hline & Dummy & 61.3 & 6.9 & & Dummy & 60.0 & 4.4 \\
\hline & Interaction & 0.3 & 0.1 & & Interaction & 0.4 & 0.1 \\
\hline & Cons. & 98.8 & 4.0 & & Cons. & 112.6 & 2.4 \\
\hline & R-squared & 0.53 & & & R-squared & 0.65 & \\
\hline \multirow[t]{5}{*}{ Dom. Rep. } & TED & 1.2 & 0.1 & Uruguay & TED & 0.6 & 0.0 \\
\hline & Dummy & 247.5 & 17.1 & & Dummy & 37.3 & 7.8 \\
\hline & Interaction & 1.5 & 0.3 & & Interaction & 0.7 & 0.1 \\
\hline & Cons. & 166.7 & 9.0 & & Cons. & 167.6 & 4.4 \\
\hline & R-squared & 0.59 & & & R-squared & 0.57 & \\
\hline \multirow[t]{5}{*}{ Ecuador } & TED & -0.5 & 0.1 & Venezuela & TED & 2.2 & 0.1 \\
\hline & Dummy & 234.6 & 46.0 & & Dummy & 922.8 & 14.7 \\
\hline & Interaction & 6.8 & 0.8 & & Interaction & -1.2 & 0.2 \\
\hline & Cons. & 713.9 & 10.5 & & Cons. & 204.3 & 11.1 \\
\hline & R-squared & 0.40 & & & R-squared & 0.82 & \\
\hline \multirow[t]{5}{*}{ El Salvador } & TED & 0.6 & 0.0 & & & & \\
\hline & Dummy & 209.0 & 7.8 & & & & \\
\hline & Interaction & 0.4 & 0.1 & & & & \\
\hline & Cons. & 141.3 & 4.5 & & & & \\
\hline & R-squared & 0.62 & & & & & \\
\hline
\end{tabular}

Source: Authors' calculations, based on Bloomberg data. 
Table 6

Correlation between the individual country CDSs and the common factor, estimated with principal components and the variance not associated with the common factor, several periods

\begin{tabular}{|l|c|c|c|c|c|c|c|c|}
\hline \multirow{2}{*}{ Country } & \multicolumn{2}{|c|}{ Full sample } & \multicolumn{2}{c|}{ Only 2007 } & \multicolumn{2}{c|}{ Before 15-09-2008 } & \multicolumn{2}{c|}{ After 15-09-2008 } \\
\cline { 2 - 8 } & Corr. & Var. & Corr. & Var. & Corr. & Var. & Corr. & Var. \\
\hline Argentina & 0.95 & $10 \%$ & 0.95 & $10 \%$ & 0.88 & $23 \%$ & 0.95 & $10 \%$ \\
Brazil & 0.99 & $2 \%$ & 0.90 & $19 \%$ & 0.94 & $12 \%$ & 0.99 & $3 \%$ \\
\hline Chile & 0.96 & $8 \%$ & 0.82 & $32 \%$ & 0.93 & $13 \%$ & 0.96 & $7 \%$ \\
\hline Colombia & 0.97 & $6 \%$ & 0.96 & $8 \%$ & 0.96 & $8 \%$ & 0.98 & $3 \%$ \\
Ecuador & -0.25 & $94 \%$ & -0.14 & $98 \%$ & -0.21 & $95 \%$ & -0.74 & $45 \%$ \\
Mexico & 0.99 & $3 \%$ & 0.99 & $2 \%$ & 0.98 & $3 \%$ & 0.99 & $3 \%$ \\
Panama & 0.98 & $4 \%$ & 0.99 & $2 \%$ & 0.99 & $2 \%$ & 0.99 & $3 \%$ \\
Peru & 0.98 & $3 \%$ & 0.98 & $4 \%$ & 0.93 & $14 \%$ & 0.98 & $3 \%$ \\
\hline Venezuela & 0.88 & $22 \%$ & 0.91 & $16 \%$ & 0.92 & $15 \%$ & 0.89 & $21 \%$ \\
\hline
\end{tabular}

Source: Authors' estimations. 
Table 7

Estimation of the common-factor model for country CDSs through a Kalman filter, with a Lehman dummy using the full sample and post Lehman sample, maximum likelihood estimations

\begin{tabular}{|c|c|c|c|c|c|}
\hline & & \multicolumn{2}{|c|}{ Full Sample } & \multicolumn{2}{|c|}{ After 15-09-2008 } \\
\hline & & Coef. & Std. Err. & Coef. & Std. Err. \\
\hline & Dummy & 0.9 & 0.1 & - & - \\
\hline \multirow[t]{2}{*}{ Argentina } & $\beta$ & 851.5 & 19.4 & 995.9 & 27.3 \\
\hline & $\alpha$ & 590.2 & 43.4 & 1421.3 & 36.0 \\
\hline \multirow[t]{2}{*}{ Brazil } & $\beta$ & 72.4 & 1.4 & 85.4 & 2.1 \\
\hline & $\alpha$ & 105.4 & 3.5 & 169.9 & 2.9 \\
\hline \multirow[t]{2}{*}{ Chile } & $\beta$ & 51.7 & 1.1 & 53.9 & 1.4 \\
\hline & $\alpha$ & 56.3 & 2.6 & 111.8 & 1.9 \\
\hline \multirow[t]{2}{*}{ Colombia } & $\beta$ & 76.4 & 1.5 & 94.7 & 2.2 \\
\hline & $\alpha$ & 121.9 & 3.8 & 183.7 & 3.2 \\
\hline \multirow[t]{2}{*}{ Ecuador } & $\beta$ & -432.6 & 41.8 & -1138.6 & 47.9 \\
\hline & $\alpha$ & 2303.7 & 55.0 & 2710.1 & 54.9 \\
\hline \multirow[t]{2}{*}{ Mexico } & $\beta$ & 81.7 & 1.7 & 90.1 & 2.2 \\
\hline & $\alpha$ & 93.2 & 4.0 & 175.9 & 3.0 \\
\hline \multirow[t]{2}{*}{ Panama } & $\beta$ & 81.2 & 1.6 & 99.7 & 2.4 \\
\hline & $\alpha$ & 107.9 & 4.0 & 175.5 & 3.3 \\
\hline \multirow[t]{2}{*}{ Peru } & $\beta$ & 75.8 & 1.5 & 88.6 & 2.2 \\
\hline & $\alpha$ & 109.6 & 3.7 & 178.2 & 3.0 \\
\hline \multirow[t]{2}{*}{ Venezuela } & $\beta$ & 458.7 & 12.2 & 433.7 & 13.6 \\
\hline & $\alpha$ & 738.8 & 24.7 & 1299.8 & 17.0 \\
\hline \multicolumn{2}{|c|}{ Log Likelihood } & -66726.1 & & -44288.9 & \\
\hline \multicolumn{2}{|l|}{ Obs. } & 1320 & & 899 & \\
\hline
\end{tabular}

Source: Authors' estimations.

Note: The number of observations refers to observations per country. We use observations for those days in which we have observations for all countries. 